\title{
The Battle Over Product Liability Law Reform
}

\author{
Theresa A. Fallon ${ }^{\dagger}$
}

Theresa Fallon is studying executive, legislative and regulatory management in the master of public administration program at The George Washington University. She has worked as a Savings and Loan Examiner for the Office of Thrift Supervision and is currently a policy specialist at The Federal Home Loan Mortgage Corporation (Freddie Mac).

A Georgia motorist recovers substantial damages from BMW after the company fails to inform him that his car received a touch-up paint job after leaving the factory. A teenager trying to steal a soft drink is injured when the machine falls on him; he successfully sues the machine's manufacturer for failing to warn him that he could be injured if he rocked the machine back and forth to dislodge-instead of pay for-the soft drink. An elderly woman is burned when hot coffee from a fast food restaurant spills onto her lap; she sues the fast food restaurant and recovers extraordinary compensation for her injuries.

For much of this century, product liability lawsuits have been used to ensure that victims are fairly compensated for injuries from defective products and shoddy workmanship. But in recent years, such lawsuits have sometimes resembled get-rich-quick schemes rather than efforts to recover reasonable damages for injuries.

To stop the flow of frivolous lawsuits and to reign in sympathetic juries, Congress undertook to reform tort law through the Common Sense Product Liability Legal Reform Act of 1996. Business interests lobbied heavily in favor of the legislation while equally powerful trial lawyers and consumer interest groups fought the bill. The opponents of reform ultimately prevailed; the 1996 legislation passed through the House and Senate during the spring of 1996 but was subsequently vetoed by President Clinton in May of that year.

Undeterred by its inability to pass this legislation in 1996, Congress has once again taken up this issue (variously referred to as "product liability reform" or "tort reform").
The Product Liability Reform Act of 1997, S. 5, was introduced by Senator John Ashcroft (R-MO) on January 21st, 1997. ${ }^{1}$ The legislation introduced is exactly the same as the failed 1996 Reform Act, but will be revised after discussions between the bill's Republican sponsors, the staff of key congressional Democrats, and Clinton administration representatives. ${ }^{2}$

Why have businesses fought so hard for federal tort reform? Conversely, why have trial lawyers and other opponents been so successful in blocking federal reform? In the past few decades, many states have recognized the need for product liability law reforms, so why has Congress been unable to reach consensus on this important policy issue? The purpose of this article is to explore the compelling arguments on both sides of product liability law reform and to discuss some of the reforms that have been successfully enacted at the state level. In addition, the possibility that meaningful reform may be passed by the 105th Congress and signed into law by President Clinton will be discussed.

\section{Key Provisions of the Federal Legislation}

The Common Sense Product Liability Legal Reform Act of 1996, if passed, would have established federal product liability laws that would supersede state law. The key provisions of the legislation were: (1) establish a maximum limit on punitive damages equal to the greater of $\$ 250,000$ or twice the sum awarded to the plaintiff for economic and non-economic losses; ${ }_{f}^{3}$ (2) give drug and medical device manufacturers an exemption from liability in cases where the Food and Drug Administration (FDA) 
has granted pre-market approval for the product; ${ }^{4}$ and

(3) eliminate joint liability for non-economic damages. ${ }^{5}$

The third provision means that each defendant in a product liability case is only liable for the amount of noneconomic loss attributable to the amount of each defendant's responsibility for the loss. ${ }^{6}$

\section{The Need for Federal Reform: Supporters' Arguments}

Although the battle over reform is being fought by special interest groups, there should be no mistaking the fact that product liability law affects us as individuals in almost every aspect of daily life. The clothes we wear, the cars we drive, the appliances we use at home, the elevators we ride to reach our offices - all are examples of items covered by product liability laws. Throughout the nation's history, each individual state has had the authority to make and enforce laws concerning the recovery of damages when a defective product causes harm.

Large and small businesses have supported product liability law reform for many years. The U.S. Chamber of Commerce, the National Association of Manufacturers, and the National Federation of Independent Businesses are among the many industry trade groups that backed the 1996 federal legislation. ${ }^{7}$ These groups and other business interests have raised a variety of economic arguments to justify the need for reform, arguing, for example, that businesses are harmed by excessively high legal costs imposed by the current system and that businesses, in turn, pass these costs to consumers in the form of higher prices. The threat and high cost of product liability lawsuits, these groups claim, also stifles innovation and thus results in fewer product choices for consumers. Supporters of federal reform say this lack of choice is particularly a problem in states that have not reformed their product liability laws.

As explained in the 1996 legislation's Conference Report: "Our Nation is overly litigious, the civil justice system is overcrowded, sluggish, and excessively costly and the costs of lawsuits, both direct and indirect, are inflicting serious and unnecessary injury on the national economy." These "costs" and the "injury" to the economy are manifested in various ways. Supporters of federal and state product liability legislation believe that the cost of goods and services available to consumers is increased due to the "excessive, unpredictable, and often arbitrary damage awards and unfair allocations of liability." 9 The American Tort Reform Association estimates that consumers pay an average of $\$ 1,200$ per person each year for product liability litigation costs. ${ }^{10}$ Of concern to supporters of federal reform is the fact that plaintiffs collect less than 50 cents of every dollar spent on the civil justice system; the remainder goes to lawyers and court costs. ${ }^{11}$

Those in favor of the legislation further argue that the current product liability legal system is extremely expensive to administer, which harms American businesses' ability to compete with foreign companies. ${ }^{12}$ According to a study by the firm Tillinghast-Towers-Perrin, lawsuits (including civil and criminal) consumed 2.3 percent of U.S. Gross Domestic Product (GDP) in 1995. In Italy and Germany, lawsuits used 1.3 percent of GDP, only 0.8 percent in England, France and Canada, and 0.7 percent in Japan. ${ }^{13}$ And according to the American Tort Reform Association, the cost of product liability insurance is 10 to 50 times higher for American manufacturers than their foreign competitors. ${ }^{14}$ Much of the money spent on our country's current system, businesses argue, could be better spent on research and development and other activities that would make U.S. companies more competitive with their foreign counterparts.

The issue of the liability system's cost was also addressed in several recent annual surveys conducted by the Association of Manufacturing Technology. Respondents to one survey-executives of machine tool manufacturing companies-indicated that companies spent 61 percent of their product liability-related costs on legal representation in 1992. Another survey showed that respondents spent more in fees to lawyers defending product liability suits in a year than they spent to purchase new machine tools to increase productivity. The companies also estimated that if the 1996 legislation had passed, their product liability 
costs would have been 44 percent lower, based on the 1996 House bill, and 56 percent lower, based on the 1996 Senate bill. ${ }^{15}$ While the costs for product liability are clearly quite considerable in the manufacturing technology industry, supporters say this is but one example of an industry that would benefit financially from reform, freeing money to be better spent on endeavors such as researching and developing better products.

Surprisingly, proponents of reform cite one of the most serious consequences of the current liability environment as a severe shortage in the raw materials used to manufacture implantable medical devices, such as pacemakers, hip and knee joints, and sutures used in surgery. ${ }^{16}$ Such products are referred to as "biomaterials." The shortage is due to a decision by many manufacturers of biomaterials to stop selling to manufacturers of implantable medical devices. This decision is caused partly by the tremendous costs incurred by biomaterials suppliers to defend their companies against product liability lawsuits. Biomaterials suppliers are frequently named in lawsuits, even when their products are found in extremely small amounts and the suppliers are not involved in the design, sale, or manufacture of the implantable device. Moreover, supporters of reform say that the raw materials suppliers are rarely found liable. Rather than risking lawsuits over a portion of their business that generates a very small percentage of their sales-most biomedical materials have commercial applications that generate far more revenue than their medical uses-biomaterials suppliers are opting to stop selling to makers of medical devices. ${ }^{17}$

Specific examples of biomaterials suppliers who are leaving the market include Biomet, Inc., which recently decided to stop selling polyethylene to manufacturers of artificial joints, and DuPont, which has halted sales of its products altogether for use in implantable devices. ${ }^{18}$ The reason for DuPont's decision is illustrated in this particularly telling example. During the 1980s, DuPont sold jaw implant manufacturers five cents worth of Teflon for each of 25,000 implants. Although DuPont was not involved in the design or manufacture of the implants, the company was named as a defendant in 259 lawsuits when the devices began breaking due to a flawed design. DuPont ultimately won all of the lawsuits, but only after spending an estimated $\$ 40$ million in legal costs over the course of five years. ${ }^{19}$
Since 1994, 12 raw material suppliers, including three major chemical companies, have ceased supplying raw materials for implantable devices. As a result, some companies have been unable to manufacture certain medical devices, leaving hospitals and doctors with critical shortages of implant devices. ${ }^{20}$ These concerns were addressed in Title II of the 1996 proposed legislation, which would have allowed biomaterials suppliers to petition the court for dismissal from a lawsuit if the supplier proved it was uninvolved in the manufacturing or selling of the device and if the raw materials met FDA specifications. ${ }^{21}$

Businesses and their trade groups also argue that the lack of uniformity among the states with respect to product liability creates uncertainty in making business decisions. Since over 70 percent of all products in the United States are sold in a state other than that in which they were manufactured, ${ }^{22}$ inconsistency in product liability laws among the states is a common and expensive problem that must be dealt with by many businesses. Some businesses have chosen not to sell their products in states where product liability laws have not been reformed. Other businesses still sell their products in such states but face the risk of owing huge damage awards and incurring significant legal costs to defend their companies against product liability lawsuits.

In addition to these concerns, businesses argue that the current tort system stifles innovation, particularly in medical products, and limits consumer choice. For example, Union Carbide decided not to pursue development of a suitcase-sized kidney dialysis unit due to potential product liability issues. And pilots of private aircraft have been unable to obtain some safety features that were developed originally for military and large commercial aircraft partly because of the risk of product liability suits. ${ }^{23}$

Most House Republicans and all but six Senate Republicans supported the 1996 federal tort reform legislation. The House leadership was particularly supportive and included the bill in the "Contract with America." The 1996 House bill was sponsored by Judiciary Committee Chairman Henry J. Hyde (R-IL), as well as Representatives Helen Chenoweth (R-ID), Jim Ramstad (R-MN), and Gary Condit (D-CA). There were numerous co-sponsors of the 
legislation, some of whom were House Democrats. ${ }^{24}$ In speaking about the House version, Congressman John Linder (R-GA), one of the bill's many co-sponsors, echoed businesses' concerns that the cost of the existing product liability system is too high and harms the financial health of American businesses and the economy. Representative

Linder also voiced the concern that the current

Businesses argue that the current tort system stifles innovation, particularly in medical products, and limits consumer choice. product liability environment has resulted in some worthy products being withdrawn from the market, especially medical devices..$^{25}$

In introducing S. 5 in January 1997, Senator Ashcroft also spoke of business-related issues when he called the bill "an attempt to bring sanity and reason to an out-of-control tort system which is hurting the quality of our products, stifling innovation and making it very difficult for some industries to survive here. I need not tell most folks that they have already made these kinds of adjustments in the European Economic Community and, of course, our competition in the Pacific Rim.. ${ }^{26}$ Hence, economic concerns are taking center stage in the current debate.

\section{Key Arguments Against Federal Product Liability Law Reform}

Most consumer interest groups and the nation's trial lawyers strenuously oppose federal product liability legislation. Many congressional Democrats were also against the 1996 legislation and may fight the current version, the details of which are now being discussed in Congress. In addition to their opposition on the basis of public policy, some Democrats said they withheld support for the original bill due to the Republican sponsors' unwillingness to compromise on certain issues.

Most consumer interest groups are strongly opposed to federal product liability law reform. Consumer groups such as Citizen Action (a three-million member organization founded by consumer advocate Ralph Nader), the Consumer Federation of America, and the National Organization for Women are a few that opposed the 1996 legislation. ${ }^{27}$
Consumer groups have said that federal tort reform that includes provisions such as those contained in 5.5 will result in the proliferation of unsafe products. These groups contend that by limiting punitive damages (damages designed to punish for a malicious, intentional act, rather than for negligence), the deterrent effect of such damages would be eroded. American businesses would then be more apt to sacrifice safety for the sake of profit. Representing Citizen Action, Robert B. Creamer testified in 1995 about the important deterrent effect of punitive damages, asserting that "they extend an economic message to corporate management that sale of dangerous products has a potential and unlimited cost. By severely limiting the amount levied for punitive damages, you send a message that the only sanction for unsafe products are slaps on the wrist." ${ }^{28}$ Opponents of limitations on punitive damages have cited examples of safety improvements in products ranging from automobiles to hand-held hair dryers that they say were made because businesses have responded in a positive manner to the threat of punitive damages. ${ }^{29}$

Consumer groups also voice concerns about the provision in the 1996 legislation that abolishes joint liability for noneconomic damages. For many years, the concept of joint and several liability has allowed plaintiffs to recover 100 percent of a damage award from any defendant who is found liable in a lawsuit, regardless of the defendant's proportion of fault in causing the damage. In contrast, several liability means that a defendant is liable only to the extent that he or she was responsible for the plaintiff's injury. In his testimony, Creamer stated that victims of gun violence would be especially harmed by the elimination of joint liability for non-economic damages. Because the perpetrator of a shooting is often jailed and frequently has limited financial resources, gun manufacturers or dealers may be the only parties who can sufficiently compensate the victim. The elimination of joint liability for noneconomic damages would thus limit the
Consumer groups have said that federal tort reform that includes provisions such as those contained in

$S .5$ will result in the proliferation of unsafe products. 
plaintiff's ability to recover an appropriate damage award. ${ }^{30}$

The 1996 federal product liability reform legislation was also firmly opposed by trade groups representing the nation's 58,000 trial lawyers. Led by the Association of Trial Lawyers of America (ATLA), trial lawyers have successfully blocked federal tort reform legislation at every opportunity. To help in this effort, ATLA and other trade associations representing attorneys gave millions of dollars in political contributions to members of Congress and the two Clinton presidential campaigns. ${ }^{31}$

Many supporters of reform believe that the primary reason most trial attorneys oppose federal legislation is due to vested financial interest in the existing system. By limiting damages that can be recovered by plaintiffs and clarifying the circumstances under which product liability lawsuits may be brought, the legislation would reduce the incomes of trial attorneys involved in such suits..$^{32}$ In an article explaining the economic aspects of product liability, law professor Richard Epstein of the University of Chicago Law School states that both defense attorneys and plaintiffs' attorneys are enriched because of the complexity of the current tort system and because of the substantial damage awards that are sometimes given to plaintiffs. ${ }^{33}$

Opponents of federal product liability reform legislation say that it is unnecessary because states have already reformed their tort laws. This argument has some validity; many states have enacted tort reform in the past several decades, as will be discussed later in this paper. Businesses contend, however, that these reforms have not brought about uniformity in state liability laws and that interstate sales of their products are risky as a result of this "patchwork" system. ${ }^{34}$

ATLA has also argued that federal tort reform is unnecessary because the frequency and level of punitive damages are not out of control, as critics of the current tort system claim. In testimony before the House Subcommittee on Commerce, Trade and Hazardous Materials, Larry Stewart, ATLA President, pointed out that one study showed there were only 355 punitive awards in product liability suits between 1965 and 1990 . When 91 asbestos cases are excluded from this count, punitive awards averaged just 11 per year in the nation during this period..$^{35}$ With respect to state courts, where most product liability cases are filed, such cases represent only 0.36 percent of civil cases. ${ }^{36}$

Those in favor of product liability reform contend that the statistics cited by ATLA's president are misleading and incorrect. For example, the same study that stated there were only 355 punitive damage awards in 25 years also says "the actual number of punitive damage awards in product liability litigation is unknown and possibly unknowable because no comprehensive reporting system exists. ${ }^{\prime \prime 37}$ Furthermore, businesses often settle out of court (even if they believe their actions were not the reason the plaintiff was harmed) in order to avoid prolonged product liability legal battles. Hence, it is impossible to fully measure the costs imposed by the current system. It remains, however, that proponents of reform are concerned not just with the awards or actual number of cases in which punitive damages are granted, but with the chilling effect such court decisions have on business decisions and the ultimate costs to businesses.

Another objection raised by ATLA is the preemption of state authority by the federal government. According to this argument, federal courts have no right to meddle in an area of law that has been under the control of states since the founding of the nation. However, this argument seems somewhat weak in light of the fact that Article I, Section 8 of the United States Constitution gives Congress the right to regulate commerce "among the several states." Since products are sold across state lines, the argument in support of federal legislation seems stronger than the argument of federal reform opponents. Many congressional Democrats would not agree with this analysis, however, and side with the trial lawyers in their argument against federal intrusion in tort law. Often during floor debate on the 1996 legislation, Democrats mentioned the irony of Republicans support for federal legislation in light of the fact that Republicans have been advocating that states be given more power in general.

Another of ATLA's key arguments is that federal legislation will not necessarily lead to more uniformity in product liability law because it will be subject to interpretation by state and federal courts. ${ }^{38}$ For example, a provision in the 1996 legislation established uniform standards in the awarding of punitive damages. Under this rule, the plaintiff must prove "by clear and convincing 
evidence that conduct carried out by the defendant with a conscious, flagrant indifference to the rights or safety of others was the proximate cause of the harm. ${ }^{\prime \prime 39}$ This provision will be subject to varying interpretations by each federal and state court unless the Supreme Court provides a national interpretation, ${ }^{40}$ Thus, although uniformity of law may be one of the primary reasons businesses advocate federal legislation, total uniformity will not likely be achieved.

Congressional opponents to the 1996 bill included influential figures in the House, such as Minority Leader Richard Gephardt (D-MO). In the Senate, the legislation was opposed by ranking minority Judiciary Committee member Ernest Hollings (D-SC) and Senator Edward Kennedy (D-MA). During floor debate on the 1996 legislation, congressional opponents articulated the same concerns raised by consumer groups and trial lawyers' trade groups. Specifically, they worried that caps on punitive damages would erode their deterrent effect. Issues surrounding the bill's supposedly unfair treatment of women, the elderly, and moderate and low-income individuals were also discussed. Finally, congressional debate indicated that some Democrats disagreed with releasing companies from liability, even if FDA approval was granted for their product.

During floor debate, some Democrats voiced opposition to the House version of the legislation because the cap on punitive damages was calculated based upon economic loss (loss of earnings, medical costs and the like), which would result in lower awards for lower-paid workers, the unemployed, senior citizens, and stay-at-home parents. ${ }^{41}$ Under this scenario, wealthy individuals would stand to receive greater awards than middle- or low-income individuals. As a result of this concern, the final version of the legislation included a cap on punitive damages that is calculated as a multiple of economic and non-economic loss.42 Pain and suffering would be factored into the calculation, thus helping to restore some sense of equality to punitive damages for wealthy versus non-wealthy individuals.

Congressional opponents of reform, including Senator Hollings, also said that the bill would result in unsafe products, echoing the objection raised by many consumer interest groups. ${ }^{43}$ Senator Hollings and other Democrats were also skeptical about claims that the awards for product liability suits are arbitrarily high; they contended that cases involving damages which are tremendously out of proportion to the situation are the exception, not the rule. Another concern raised by federal product liability reform opponents is that the legislation is inappropriate because it weakens the tort reform system at a time when federal regulations are being relaxed and enforcement budgets are being cut during the appropriations process. Senator Edward Kennedy (D-MA) called this an "assault" on the "twin pillars" that protect consumers: tort.law and federal regulation. ${ }^{14}$

\section{The Presidential Response to Federal Reform}

Despite public statements in support of tort reform, President Clinton vetoed the Common Sense Product Liability Legal Reform Act on May 2, 1996. In a letter to then-Senate Majority Leader Robert J. Dole (R-KS) in March 1996, Clinton indicated that he would veto the bill for several reasons. First, President Clinton believed that the legislation would displace state law and would do so only when it was more beneficial for businesses, not consumers. He called the proposed law an "unwarranted intrusion on state authority." ${ }^{\prime 45}$ Second, he was concerned about the elimination of joint liability since it would be more difficult for victims to be fully compensated for their injuries. Third, Clinton expressed opposition to the punitive damage limitations in the legislation. ${ }^{46}$

Proponents of the bill said that President Clinton used these reasons as convenient excuses to veto the legislation, pointing to the fact that Clinton had supported federal product liability legislation during his terms as governor of Arkansas. Critics of the President also said that his concerns about the punitive damage limitation were exaggerated. In his letter to Senator Dole, Clinton said, "For those irresponsible companies willing to put profit above all else, the bill's capping of punitive damages increases the incentive to engage in egregious misconduct of knowingly manufacturing and selling defective products." ${ }^{\prime 47}$ The sponsors of the 1996 bill say this argument is invalid because, as a result of White House concerns, the bill included a provision for the punitive damage cap to be overridden if the defendant was found to have engaged in "egregious misconduct." 48

With respect to President Clinton's concern about the elimination of joint liability, the legislation's backers point 
out that joint liability is not eliminated for economic damages. Hence, plaintiffs can still recover the costs of medical bills, lost wages, and other compensatory damages by suing defendants with the strongest financial capacity to pay, even if those defendants shared only a small part of the blame for the injury.

Although it was not stated publicly by the White House, another reason for Clinton's veto was political. Both supporters and opponents of the legislation claim that the issue of product liability legal reform was used to portray congressional Republicans (and among them, Republican presidential candidate Robert Dole) as putting the interests of business ahead of consumers. ${ }^{49}$

\section{Confounding the Debate For and Against Reform: Political Contributions}

Some critics of President Clinton say the real reason behind the veto was that the president is beholden to trial lawyers for financial support. These critics cite statistics showing that lawyers and law firms have consistently contributed to President Clinton's campaigns and were the top financial backers of Clinton's re-election campaign, contributing $\$ 2.5$ million in the first nine months of $1995 .{ }^{50}$ These critics charge that President Clinton's opposition on the basis that the legislation does not adequately protect consumers is merely a convenient pretext.

Similarly, some have speculated that the positions in the debate taken by certain members of Congress were due to financial self-interest. A 1995 article in Forbes magazine showed that some of the 1996 legislation's key opponents were among the top recipients of political contributions from attorneys between 1989 and 1994. For example, Senator Edward Kennedy (D-MA) received about $\$ 139,000$ from trial lawyers during that time period and Senator Ernest Hollings (D-SC) received approximately $\$ 163,000 .{ }^{51}$ Critics also suggest that in addition to the $\$ 14$ million raised by ATLA's political action committee since 1989, over $\$ 18$ million in contributions were steered by about 3,000 trial lawyers to congressional candidates. ${ }^{52}$

Opponents of reform are no less quick than supporters to point out how political contributions influence members of Congress to favor tort reform. Business groups in favor of federal product liability legislation contributed almost $\$ 30$ million to members of Congress between 1993 and
1996..$^{53}$ Another source estimates that corporations and other groups supporting the legislation gave almost $\$ 6$ million to members of Congress in 1995. ${ }^{54}$ However, it is difficult to determine whether businesses or trial attorneys spend more on product liability reform. This is because business trade groups contribute to members of Congress in order to influence a larger range of issues than trial attorneys, who are interested primarily in two pieces of legislation: tort reform and securities law. In addition, attorneys and business persons often contribute as individuals, increasing the difficulty in estimating the total amount given. ${ }^{55}$ As a result, it is impossible to be certain of the extent to which campaign contributions determined the positions taken by members of Congress on product liability reform. Nevertheless, the lavish sums spent by both sides on the debate no doubt had some influence on the legislative process.

\section{Reform Of Product Liability Law On the State Level}

Although the battle for federal tort reform has not yet been won, many states have reformed their tort laws. In fact, a number of states have adopted statutes that are similar to the provisions of S. 5. Especially prevalent in state changes have been limitations on, or the abolition of, joint and several liability. As mentioned previously, the federal legislation proposes to eliminate joint liability for noneconomic damages, but the defendant is still liable for non-economic losses in proportion to the amount of his or her responsibility for the loss.

As of December 1996, 31 states had enacted changes to their laws regarding joint and several liability. The following table shows the type of reform adopted by each state. ${ }^{56}$

In addition to the seven states that abolished joint and several liability, 11 states have limited or abolished joint and several liability in some cases, depending upon the proportion of fault by the plaintiff or defendant. For product liability cases in Georgia, for example, there is no joint liability if the plaintiff is partly at fault for the 


\begin{tabular}{|l|l|l|}
\hline $\begin{array}{c}\text { Joint and Several } \\
\text { Liability Abolished }\end{array}$ & $\begin{array}{c}\text { Joint and Several } \\
\text { Liability Limited or } \\
\text { Abolished Based upon } \\
\text { Proportion of Fault }\end{array}$ & $\begin{array}{c}\text { Joint and Several } \\
\text { Liability Limited or } \\
\text { Abolished - with } \\
\text { Caveats }\end{array}$ \\
\hline $\begin{array}{l}\text { Alaska, Arizona (unless } \\
\text { harm is intentional), } \\
\text { Illinois, Louisiana, Utah, }\end{array}$ & $\begin{array}{l}\text { Georgia, Kentucky, } \\
\text { Mermont, Wyoming } \\
\text { Montana, New } \\
\text { Hampshire, New Jersey, } \\
\text { Ohio, South Dakota, } \\
\text { Texas, Wisconsin }\end{array}$ & $\begin{array}{l}\text { Arizona, California, } \\
\text { Colorado, Connecticut, } \\
\text { Florida, Hawaii, Idaho, } \\
\text { Michigan, Mississippi, } \\
\text { Nebraska, New York, } \\
\text { Oregon, Washington }\end{array}$ \\
\hline
\end{tabular}

liability (as seven states have done), Congress has followed the example of the states in proposing changes to the concept of joint and several liability.

Many states have limited the amount of punitive damages that can be awarded in products cases in recent years. In keeping with reforms at the state level, S. 5 also limits punitive damages. The pending federal legislation says that plaintiffs can only

damage or harm. Other examples include Texas and Wisconsin, which abolished joint liability if the defendant is less than 51 percent at fault.

Thirteen states have limited or abolished joint and several liability, but with caveats, meaning that the circumstances vary by state and depend upon factors other than the proportion of fault assigned to the plaintiff and/or defendant. For example, California abolished joint and several liability for non-economic damages only (like the proposed federal legislation), while Oregon abolished joint liability except for cases in which a defendant becomes insolvent within one year of the final judgment. Each of the other 11 states in this category established criteria that dictate whether joint and several liability will be applied or waived in a product liability lawsuit.

The fact that 31 states have adopted reforms dealing with the concept of joint and several liability shows that the current federal proposals to abolish joint liability for non-economic damages is in line with trends at the state level. Although the proposed federal reform is not as stringent as completely eliminating joint and several

\begin{tabular}{|c|c|c|c|}
\hline State & Punitive Damages Maximum & State & Punitive Damages Maximum \\
\hline Illinois & Three times economic damages & $\begin{array}{l}\text { North } \\
\text { Carolina }\end{array}$ & $\begin{array}{l}\text { Greater of } \$ 250,000 \text { or three times } \\
\text { compensatory damages (see note) }\end{array}$ \\
\hline Indiana & $\begin{array}{l}\text { Greater of } \$ 50,000 \text { or three times } \\
\text { compensatory damages }\end{array}$ & Ohio & $\begin{array}{l}\text { Greater of } \$ 250,000 \text { or three times } \\
\text { amount of compensatory damages } \\
\text { for large employers (>25 } \\
\text { employees); all others: lesser of } \\
\$ 100,000 \text { or three times } \\
\text { compensatory damages }\end{array}$ \\
\hline Kansas & $\begin{array}{l}\text { Lesser of defendant's annual } \\
\text { gross income or } \$ 5 \text { million (see } \\
\text { note) }\end{array}$ & Oklahoma & $\begin{array}{l}\text { Varies, depending upon } \\
\text { circumstances }\end{array}$ \\
\hline $\begin{array}{l}\text { New } \\
\text { Jersey }\end{array}$ & $\begin{array}{l}\text { Greater of } \$ 350,000 \text { or five times } \\
\text { compensatory damages (see note) }\end{array}$ & Texas & $\begin{array}{l}\text { Greater of } \$ 200,000 \text { or two times } \\
\text { economic damages plus } \\
\text { non-economic damages up to } \\
\$ 750,000\end{array}$ \\
\hline $\begin{array}{l}\text { North } \\
\text { Dakota }\end{array}$ & $\begin{array}{l}\text { Greater of } \$ 250,000 \text { or two times } \\
\text { compensatory damages }\end{array}$ & Virginia & $\$ 350,000$ maximum \\
\hline Florida & $\begin{array}{l}\text { Three times compensatory } \\
\text { damages, unless "clear and } \\
\text { convincing evidence" that higher } \\
\text { award is not excessive }\end{array}$ & $\begin{array}{l}\text { New } \\
\text { Hampshire }\end{array}$ & Punitive damages prohibited \\
\hline
\end{tabular}

Note: Punitive damage award may be greater than cap shown above, depending upon the circumstances of the case. recover the greater of $\$ 250,000$ or twice the sum awarded for economic and non-economic losses. However, the judge may increase the amount of punitive damages if the defendant's actions were deemed to be egregious and the damage amount is considered to be insufficient to deter such behavior in the future. ${ }^{57}$ Maximum amounts for punitive damages are now in place in 12 states, as shown in the table below. ${ }^{58}$ As with the issue of joint and several liability, the reforms vary from state to state. 
The notion of limiting punitive damages is a common element in both federal and state legislation. But it is difficult to compare the proposed federal reforms to the changes passed by the states since there are several variables to consider. The pending bill is similar to some state reforms in that punitive damages are the greater of a fixed amount or some multiple of other damages awarded. However, the fixed amount of the award varies among some states and the federal legislation, as does the multiple in a few cases. Moreover, not all of the state reforms use economic and non-economic damages as the amount to be multiplied, as does the federal legislation.

The pending federal legislation includes a provision that biomaterials suppliers are not liable for harm done to the plaintiff if the FDA has approved the product for marketing. ${ }^{59}$ Because this section of the bill deals only with suppliers of raw materials for medical devices, it is more limited than the reforms adopted by the eight states that take FDA or other agency approval into account in product liability lawsuits. For example, Michigan provides for a defense based on FDA approval for biomaterials and other products, and goes a step further to allow that a product manufacturer is not liable if a product complied with federal or state standards. ${ }^{60}$

Another example of a state with broader reforms relating to FDA approval is New Jersey. In 1987, New Jersey established a law that mandates that for drugs, medical devices, food, and food additives that are approved, licensed, or regulated by the FDA, punitive damages may not be assessed against the defendant unless material information was withheld or misrepresented. ${ }^{61}$

Although many states have reformed their product liability laws, some of the new laws have been challenged in court. In Illinois, Cook County Circuit Court Judge Kenneth Gillis ruled that the $\$ 500,000$ limit on noneconomic damages was unconstitutional. One of the reasons for the ruling is that, according to Judge Gillis, the cap violates a citizen's right to a trial jury by taking away the jury's decision-making ability. ${ }^{62}$ Defense attorneys have appealed Judge Gillis' decision to the Illinois Su- preme Court for a ruling in Cargill v. Waste Management. ${ }^{63}$ In response to the limit $S .5$ places on punitive damages, plaintiffs' attorneys could attempt to make a similar argument if the federal legislation passes.

Challenges to state product liability laws are not unusual, according to an attorney at the Chicago law firm of Power Rogers \& Smith. According to attorney Todd. Smith, about 25 state tort reform laws are being appealed. Smith says that many of the legal challenges question the merit of punitive and compensatory damage award caps. ${ }^{64}$

The ruling of Judge Gillis and the fact that tort reform laws have been challenged in a number of states suggests that even though reform may be enacted at the state level, some of these reforms may not survive judicial review. Reform at the federal level would likewise be subject to court challenges and differing interpretations.

\section{The Future of Reform}

For over two decades, businesses have pushed for product liability law reform and their efforts have succeeded in some states. But supporters of liability reform-whose efforts temporarily faltered when President Clinton vetoed the Common Sense Product Liability Legal Reform Act of 1996-are not giving up on the possibility that federal tort reforms may yet be enacted. Product liability law is once again on the agenda in Congress, and negotiations as to the bill's content are underway between key sponsors of S. 5 and the Clinton administration as this article goes to press. Given the strong arguments on both sides of this issue, and the powerful (and wealthy) interests that are aligned against one another, what are the chances that the 105th Congress will pass a reform bill? And if such a bill passes, what form will it take?

As compelling as the arguments for reform may be, any federal reform that is enacted by the 105th Congress will likely be a compromise version of the 1996 legislation. The Senate leadership has said that Republicans are willing to work with the White House to enact reform, but maintains that they will not accept significant changes to last year's bill. However, Victor Schwartz, an attorney and advocate 
of reform who advises the Product Liability Coordinating Committee, believes that the Republicans are more willing to compromise this year. Schwartz says that the 1997 bill will be more limited, less of a "smorgasbord," and thus will be more likely to become law. ${ }^{65}$

Assuming federal legislation passes, it is impossible to predict whether President Clinton will approve the bill. There are a few considerations, however, that make a Clinton veto less likely to occur in future legislation. With the pressure of the presidential election over, there is less incentive to use this as a political issue against Republicans (i.e., to charge that Republicans are putting business interests ahead of those of consumers). The scandals regarding campaign fundraising practices may also make President Clinton more vulnerable to critics who say that a veto of the legislation would prove that he is rewarding his top financial contributors, the nation's trial lawyers. The level of Clinton's publicly-stated commitment to tort reform may well be tested if Congress successfully completes legislation for his signature.

The need for reform has been convincingly argued by the private sector, and Congress once again has taken up the cause of tort reform. Ultimately, lawmakers will have to successfully balance the arguments of businesses against the need to ensure that victims are justly compensated for injuries caused by defective products. Hopefully, policymakers will put the public good ahead of money and political considerations in making a decision on the legislation. But as is often the case with the legislative process, the group with the most powerful lobbyists, the most money, and the best political connections may end up winning the battle.

\section{Notes}

II wish to thank Scott Haggard, Mary Beth Morgan, RacheI Mosher-Williams, and Jill Kasle for their comments and editorial assistance. This article is dedicated to my father, Earl F. Chandler.

${ }^{1}$ Congressional Record, 105th Cong., 1st sess., 21 January 1997, S226.

2Mary Lehman, "Product Liability Talks to Begin," National Journal's Congress Daily/A.M., 3 March 1997, 1.

${ }^{3}$ House, Conference Report to Accompany H,R. 956, Common Sense Product Liability Legal Reform Act of 1996, 104th Cong., 2d sess., 1996, H. Rept. 104-481, 10. For small businesses, the award could not exceed the lesser of these two amounts.

${ }^{4}$ Ibid., 10.

${ }^{5}$ Ibid., 12.

${ }^{6}$ Ibid.

${ }^{7}$ Congressional Record, 104th Cong,, 2d sess., 21 March 1996, S2563.

${ }^{8}$ House, Conference Report to Accompany H.R. 956, 2. 138.

${ }^{10}$ American Tort Reform Association, Tort Reform Questions and Answers (n.d.)

11 "The Lawyers' Veto," The Wall Street Journal, 3 May 1996, A12.

${ }^{12}$ Novack, "Torture by Tort," 138.

${ }^{13}$ Ibid.

14 "The Lawyers' Veto," A12.

${ }^{15}$ American Tort Reform Association, Tort Reform Questions and Answers.

${ }^{16}$ House Committee on Commerce, Subcommittee on Com- merce, Trade and Hazardous Materials, Hearing on the Common Sense Product Liability Reform Act of 1995, 104th Cong., 1st sess., 1995, 43-44.

${ }^{17}$ Joseph Lieberman and John McCain, "Lifesavers and Lawsuits," The Washinton Post, 3 April 1996, A19.

${ }^{18}$ Ibid.

${ }^{19}$ John Stossel, "Protect Us From Legal Vultures," The Wall Street Joumal, 2 January 1996, A8.

${ }^{20}$ Lieberman and McCain, "Lifesavers and Lawsuits," A19.

${ }^{21}$ Tbid.

${ }^{22}$ House, Conference Report to Accompany H.R. 956, 21.

${ }^{23}$ House Committee on Commerce, Subcommittee on Commerce, Trade and Hazardous Materials, Hearing on the Common Sense Product Liability Reform Act of 1995, 8.

${ }^{24}$ Ibid., 39-40.

${ }^{25}$ Congressional Record, 104th Cong., 1st sess., 10 January 1995, H161.

${ }^{26} \mathrm{Tbid}$. S226.

${ }^{27}$ Congressional Record, 105th Cong., 1st sess., 21 January 1997,

${ }^{28}$ Congressional Record, 104th Cong., 2d sess., 21 March 1996, S2557.

${ }^{29}$ House Committee on the Judiciary, Common Sense Legal Standards Reform Act of 1995, H.R. 956, 104th Cong., 1st sess., 1995, H. Rept, 104-63, 68.

${ }^{30}$ Tracy Benson, "Product Liability: Deep Waters to Debate," Industry Week, 6 August 1990, 51.

${ }^{31}$ House Committee on the Judiciary, Hearing on the Product Liability Fairness Act, 103rd Cong., 2d sess., 1995, 173.

${ }^{32}$ Saundra Torry, "You'll Never Guess Who Really Won the Liability Fight," The Washington Post, 16 September 1996, 31. 
${ }^{33}$ Richard A. Epstein, "The Political Economy of Product Liability Reform," American Economic Revievv 78, no. 2 (1988): 313.

${ }^{34}$ Ibid.

${ }^{35}$ Catherine Yang, "Tort Reform Needs Reforming," Business Week, 15 April 1996, 67.

${ }^{36}$ House Committee on Commerce, Subcommittee on Commerce, Trade and Hazardous Materials, Hearing on the Common Sense Product Liability Reform Act of 1995, 29.

${ }^{37}$ Ibid., 27.

${ }^{38}$ Ibid., 22.

${ }^{39} \mathrm{Ibid} ., 31$. S228.

${ }^{40}$ Congressional Record, 105th Cong., 1st sess., 21 January 1997,

${ }^{41}$ Henry Cohen, "Products Liability, A Legal Overview," CRS Issue Brief, 5 February 1997.

${ }^{42}$ Congressional Record, 104th Cong., 1st sess., 9 March 1995, $\mathrm{H} 2910$.

${ }^{43}$ House, Conference Report to Accompany H.R. 956, 10.

${ }_{44}$ Congressional Record, 104th Cong., 2d sess., 21 March 1996, S2567.

${ }^{45} \mathrm{Ibid} ., \mathrm{S} 2555$.

${ }^{46}$ Ibid.

${ }^{47}$ Neil A. Lewis, "President Promises to Veto Product Liability Legislation," The New York Times, 17 March 1996, 30.

${ }^{48}$ Ibid. S228.
${ }^{50}$ Richard B. Schmitt, "Planned Veto of Liability Bill is Businesses' Loss," The Wall Street Journal, 18 March 1996, A2.

${ }^{51}$ John M. Broder, "Clinton Vetoes Bill to Limit Product Liability Lawsuits," Los Angeles Times, 3 May 1996, A15.

${ }^{52}$ Novack, "Torture by Tort," 140.

${ }^{53}$ Ibid., 141.

${ }^{54}$ Ann DeVroy and Helen DeWar, "Product Liability Pits Two Goliaths,'” The Washington Post, 26 March 1996, Al.

${ }^{55}$ Jube Shiver, "Clinton Vows to Veto Measure on Product Liability, Los Angeles Times, 17 March 1996, A14. A6.

${ }^{56}$ DeVroy and DeWar, "Product Liability Pits "Two Goliaths',"

${ }^{57}$ American Tort Reform Association, Tort Reform Record, informational bulletin (n.d.).

${ }^{58}$ Congressional Record, 105th Cong., 1st sess., 21 January 1997, S228.

${ }^{59}$ American Tort Reform Association, Tort Reform Record. S231.

${ }^{60}$ Congressional Record, 105th Cong., 1st sess., 21 January 1997,

${ }^{61}$ American Tort Reform Association, Tort Reform Record.

${ }^{62}$ Ibid., 20.

${ }^{63}$ Mark Brown, "Cap on Jury Awards Lifted," Chicago SunTimes, 23 May 1996, A1.

${ }^{64}$ Darryl Van Duch, "Illinois Reform: A Cautionary Tale," The National Law Journal, 9 December 1996, A21.

${ }^{66}$ Mary Lehman, "Product Liability Talks to Begin," 4.

\section{Bibliography}

American Tort Reform Association. Tort Reform Record, informational bulletin, n,d.

American Tort Reform Association. 1996 Tort Reform Enactments, informational bulletin, $\mathrm{n}$.d.

American Tort Reform Association. 1995 Tort Reform Enactments, informational bulletin, n.d.

American Tort Reform Association. A Few Facts About Product Liability, n.d.

American Tort Reform Association. Tort Reform Questions and Answers, n.d.

Benson, Tracy. "Product Liability: Deep Waters to Debate." Industry Week, 6 August 1990, 46-63.

Bennet, James. "Business Groups Hope Ads in Pivotal Electoral States Sway Clinton on Product Liability Bill." The New York Times, 30 April 1996, B8.

Broder, John M. "Clinton Vetoes Bill to Limit Product Liability Lawsuits." Los Angeles Times, 3 May 1996, A1.

Brown, Mark. "Cap on Jury Awards Lifted." Chicago Sun-Times, 23 May 1996, A1.

Cohen, Henry. "The Product Liability Bill Vetoed in the 104th Congress and Introduced as S. 5, 105th Congress." CRS Report for Congress, 5 February 1997.

. "Products Liability: A Legal Overview." CRS Issue Brief, 5 February 1997.

Cohen, Henry, and La Vonne Mangan. "Fifty-State Surveys of Selected Products Liability Issues." CRS Report for Congress,
20 June 1995.

Congressional Record. 104th Cong., 1st and $2 \mathrm{~d}$ sessions, 10 January 1995, 9 March 1995, 21 March 1995, 20 March 1996 and 21 March 1996.

Congressional Record. 105th Cong., 1st sess., 1997. 21 January 1997.

DeMott, John S. "Product-Liability Reform...Maybe." Nation's Business, April 1995, 32-33.

DeVroy, Ann, and Helen DeWar. "Product Liability Pits "Two Goliaths'." The Washington Post, 21 March 1996, A1.

DeWar, Helen. "2 Senate Democrats Join Business Critics of Clinton on Product-Liability Bill." The Washington Post, 19 March 1996, A4.

Epstein, Richard A. "The Political Economy of Product Liability Reform." American Economic Review 78, no. 2 (May 1988): 311315 .

Frum, David. "Sanity is Back in Style." Forbes, 2 August 1993, 62.

Gray, Greg. "Clinton Shows Common Sense by Vetoing Product Liability Act." The Indiana Lawyer, 15 May-28 May 1996, 4.

Hamilton, Martha M. "Conferees Agree on Limits to Product Liability Awards." The Washington Post, 14 March 1996, A1.

Hamilton, Martha M. "Conferees Work on Product Liability Bill." The Washington Post, 9 March 1996, D2.

Harris, John F. "Clinton Vetoes Product Liability Measure." The Washington Post, 3 May 1996, A14.

Harwood, John. "A Freshman GOP Senator Grabs an Opportunity to Dislodge Logjam in Product-Liability Reform." The Wall Street Journal, 25 April 1995, A22. 
Hook, Janet, and Elizabeth Shogren. "House OKs Limits in Product Liability Suits." Los Angeles Times, 30 March 1996, A1.

Jacobs, Margaret A. "Legal Beat: Civil Rights Groups Fear Fast Senate Step." The Wall Street Journal, 21 April 1996, B16.

Kolata, Gina. "A Case of Justice, or a Total Travesty?" The New York Times, 13 June 1995, D1.

Keuterman, Greg. "Appelate Court Says No to Retroactivity." The Indiana Lawyer, 29 May-11 June 1996, 6.

"Tort Challenge in Illinois Raises Hopes of ITLA." The Indiana Lawyer, 1 May-14 May 1996, 3.

Kuttner, Robert. "Defending the Defenders." Boston Globe, 1 April 1996, 19.

Labaton, Stephen. "Don't Sue, They Say, We Went Bankrupt." The New York Times, 21 May 1995, sec. 4, p. 16.

"Playing with the Words in the Product Liability Bill." The New York Times, 5 March 1995, 16.

Lehman, Mary. "Product Liability Talks to Begin." National Journal's Congress Daily/A.M, 3 March1997, 1.

Lewis, Neil A. "House Approves Measure to Limit Federal Lawsuits." The New York Times, 8 March 1995, A1

"President Promises to Veto Product Liability Legislation." The New York Times, 17 March 1996, sec. 1, p. 30.

Lieberman, Joseph, and John McCain. "Lifesavers and Lawsuits." The Washington Post, 3 April 1996, A19

Mayer, Caroline E. "Getting Personal on Product Liability." The Washington Post, 7 March 1996, D1.

McCarthy, Colman. "Principled Stand Against Liability 'Reform'." The Washington Post, 26 March 1996, C12.

Metzenbaum, Howard. "Faulty Products, Faulty Bill." The Washington Post, 17 May 1996, A23.

Novack, Janet. "Torture by Tort." Forbes, 6 November 1995, 138141.

Pearlstein, Steven, and Frank Swoboda, "Labor versus Business: Mixed Election Results and More Modest Goals." The Washington Post, 10 November 1996, H5.

Roberts, Sally. "Plaintiff Requirement Ruled Unconstitutional." Business Insurance, 7 October 1996, 26.

Rowland, J. Roy, and Louis W. Sullivan. "Supply Side Medicine." Nezu York Times, 4 April 1996, A25.

Schmitt, Richard B. “Legal Beat: For Lawyer Lobbying for Tort Overhaul, 15 Years of Schmoozing Finally Pays Off." The Wall Street Journal, 11 April 1995, B1.

"Panel Revises Bill to Include a Break for Charity Groups." The Wall Street Journal, 11 March 1996, B5.

"Planned Veto of Liability Bill is Business's Loss." The Wall Street Journal, 18 March 1996, A2.
Shiver, Jube. "Clinton Vows to Veto Measure on Product Liability." Los Angeles Times, 17 March 1996, A1.

Shogren, Elizabeth. "Senate Votes to Cap Awards in Product Liability Suits." Los Angeles Times, 22 March 1996, A15.

Stossel, John. "Protect Us From Legal Virtues." The Wall Street. Journal, 2 January 1996, A8.

Editorial. "The Lawyers' Veto." The Wall Street Journal, 3 May 1996, A16.

Torry, Saundra. "You'Il Never Guess Who Really Won the Liability Fight." The Washington Post, 16 September 1996, 31.

U.S. Congress. House. Committee on Commerce. Common Sense Product Liability Reform Act of 1995, H.R. 917. 104th Cong., 1st sess., 1995. H. Rpt. 104-63.

U.S. Congress. House. Committee on Commerce, Subcommittee on Commerce, Trade, and Hazardous Materials. Hearing on the Common Sense Product Liability Reform Act of 1995, H.R. 917. 104th Cong., 1st sess., 1995.

U.S. Congress. House. Committee on the Judiciary. Common Sense Legal Standards Reform Act of 1995, H.R. 956. 104th Cong., 1st sess., 1995. H. Rpt. 104-64.

U.S. Congress. House. Conference Report to Accontpany H.R. 956, Common Sense Product Liability Legal Reform Act of 1996. 104th. Cong,, 2d sess; 1996.

U.S. Congress. Senate. Committee on Commerce, Science, and Transportation. Product Liability Fainness Act. 104th Cong., 1st sess., 1995, S. Rpt. 104-69.

U.S. Congress. Senate. Committee on the Judiciary. Hearing on the Product Liability Fairness Act. 103rd Cong., 2d sess, 1994.

Van Duch, Darryl. "Damages Cap Struck Down in Illinois." The National Law Jourhal Regional Reports, 3 June 1996, A1.

. "Illinois Tort Reform: A Cautionary Tale." The National Law Journal, 9 December 1996, A1.

Vuernick, Richard. "We Need Protection from Defective Products." The Wall Street Journal, 25 March 1996, A15.

West, Peg. "Deadline Creates Rush to Judgment." Grand Rapids Press, 28 March 1996, A1.

Yang, Catherine. "Tort Reform Needs Reforming." Business Week, 15 April 1996, 67.

"Maybe Clinton Saw Red Over a Green." Business Week, 1 April 1996, 6.

" "Snatching Defeat from the Jaws of Victory." Business Week, 1 August 1994, 76-77.

Zollers, Francis E., and Ronald G. Cook. "Product Liability Reform: What Happened to the Crisis?" Business Horizons, September/October 1990, 47-52. 